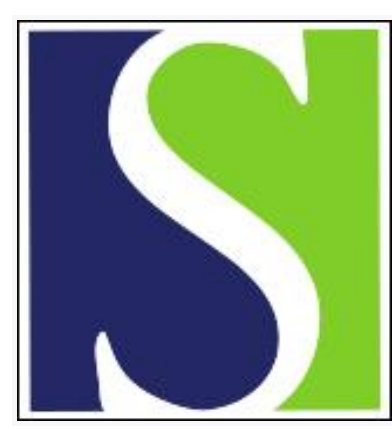

Scand J Work Environ Health 1999;25(4):326-334

https://doi.org/10.5271/sjweh.442

Issue date: Aug 1999

Increased CD3 positive cells in bronchoalveolar lavage fluid after hydrogen fluoride inhalation

by Lund K, Refsnes M, Sandstrøm T, Søstrand P, Schwarze P, Boe J, Kongerud J

Key terms: bronchoalveolar lavage; fluorides; inflammation

This article in PubMed: www.ncbi.nlm.nih.gov/pubmed/10505658

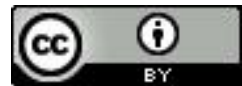




\title{
Increased CD3 positive cells in bronchoalveolar lavage fluid after hydrogen fluoride inhalation
}

\author{
by Kristin Lund, MD, ${ }^{1}$ Magne Refsnes, PhD, ${ }^{2}$ Thomas Sandstrøm, MD, ${ }^{3}$ Per Sostrand, PhD, ${ }^{4}$ Per \\ Schwarze, PhD, ${ }^{2}$ Jacob Boe, MD, ${ }^{1}$ Johny Kongerud, $M D^{1}$
}

\begin{abstract}
Lund K, Refsnes M, Sandstrøm T, Søstrand P, Schwarze P, Boe J, Kongerud J. Increased CD3 positive cells in bronchoalveolar lavage fluid after hydrogen fluoride inhalation. Scand J Work Environ Health 1999;25(4):326334.

Objectives This study examined whether experimental hydrogen fluoride exposure for 1 hour induces an inflammatory response in the lower respiratory tract that is detectable in bronchoalveolar lavage fluid.

Methods Nineteen healthy, nonsmoking men were exposed for 1 hour to constant low $\left(\leq 0.6 \mathrm{mg} / \mathrm{m}^{3}\right)$, intermediate $\left(0.7-2.4 \mathrm{mg} / \mathrm{m}^{3}\right)$, or high $\left(2.5-5.2 \mathrm{mg} / \mathrm{m}^{3}\right)$ concentrations of hydrogen fluoride. Bronchoalveolar lavage was performed at least 3 weeks before and 24 hours after the exposure. For 15 subjects differential countings were performed.

Results There was a significant increase in the percentage of $\mathrm{CD} 3$ positive cells in the bronchial portion for those exposed to "intermediate" and "high" concentrations. For the "high" exposure group the increase in the bronchoalveolar portion was also significant. A significant correlation was found between the increase in the percentage of lymphocytes and CD3 positive cells in the bronchoalveolar portion (Spearman's coefficient $r=0.68, P=0.008$ ). Myeloperoxidase and interleukin-6 increased significantly in the bronchial portion for those exposed to "high" concentrations. There was a significant increase in myeloperoxidase $(\mathrm{P}=0.005)$ for all the exposures, while there was a decrease in E-selectin $(\mathrm{P}=0.007)$.

Conclusions Hydrogen fluoride may induce an inflammatory reaction in the airways at concentrations that can occur in the ambient air in the primary aluminum industry.
\end{abstract}

Key terms bronchoalveolar lavage, fluorides, inflammation,

Asthma is known as a major health problem in primary aluminum production $(1,2)$. Epidemiologic studies have demonstrated associations between fluoride exposure and asthmatic symptoms among potroom workers $(1-3)$. An increased occurrence of bronchial hyperresponsiveness, a major feature of asthma, has even been reported for children living in the vicinity of an aluminum plant (4). An increase in albumin and fibronectin in bronchoalveolar lavage (BAL) fluid has been found in aluminum potroom workers (5) and may indicate that there is an inflammatory process in the airways. The causal agent for these effects is still unknown.

Hydrogen fluoride is quantitatively one of the most important gaseous pollutants in the environment of the primary aluminum industry. Since asthma is associated with airway inflammation $(6,7)$, it has been suggested that low doses of hydrogen fluoride, known as a respiratory irritant, may cause inflammatory reactions in lower airways (8). In previous experiments we did not find any changes in lung function when evaluated by measurements of forced expiratory volume in 1 second $\left(\mathrm{FEV}_{1.0}\right)$ (9). Symptoms from upper airways dominated at the end of the exposure, and they significantly correlated with the hydrogen fluoride exposure concentration, the change in plasma fluoride concentration, and maximum plasma fluoride levels. However, no symptoms were reported 24 hours after the exposure (9).

The aim of our present study was to test the hypothesis that hydrogen fluoride may cause an inflammatory cell response in the human respiratory tract, as reflected

1 Department of Thoracic Medicine, The National Hospital, University of Oslo, Norway.

2 Department of Environmental Medicine, National Institute of Public Health, Oslo, Norway.

3 Department of Pulmonary Medicine and Allergology, University Hospital and National Institute for Working Life, Medical Division, Umeå, Sweden.

4 National Institute of Occupational Health, Oslo, Norway.

Reprint requests to: Dr Kristin Lund, Department of Thoracic Medicine, The National Hospital, University of Oslo, N-0027 Oslo, Norway. [E-mail: ] 
in changes in lymphocytes, CD3 positive cells, and neutrophils in BAL fluid. We also wanted to investigate whether there were indications of changes in soluble components at different hydrogen fluoride concentrations.

\section{Subjects and methods}

\section{Subjects}

Nineteen healthy, nonsmoking male volunteers, students or health personnel, aged $21-44$ years participated in the study. None of the participants had been exposed occupationally to fluorides before. Subjects with any airway infection for the 6 weeks prior to the study or during the study period or with a history of asthma were excluded. Two subjects had hay fever, and one of them had an increased total immunoglobulin $\mathrm{E}$ (IgE) value of $210 \mathrm{kU} / \mathrm{l}$ (upper normal value $122 \mathrm{kU} / \mathrm{l}$ ). Another subject had an increased total $\mathrm{IgE}$ level $(220 \mathrm{kU} / \mathrm{l})$ without having a history of allergy. All the subjects had normal chest X-ray results prior to inclusion in the study. The spirometry values were within the reference range with regard to forced vital capacity (FVC) and forced expiratory volume in 1 second $\left(\mathrm{FEV}_{1.0}\right)$ (10). Everyone had blood sample values (hemoglobin, sedimentation rate, leucocytes, eosinophils, electrolytes, and liver and renal function tests) within the normal reference range. The study was approved by the local ethics committee, and the subjects gave their signed informed consent before they were included in the study.

\section{Study design}

Three weeks after a reference BAL, the subjects were exposed to hydrogen fluoride for 1 hour. Fiberoptic bronchoscopy with BAL was performed 24 hours after the start of the hydrogen fluoride exposure, and the data obtained by analyses of the BAL fluid were compared with the results of the analyses of the reference BAL fluid. Each subject served as his own control.

\section{Hydrogen fluoride}

Hydrogen fluoride is a colorless gas with a pungent odor. It is highly water soluble, and, even though weakly dissociated in water, it is a strong proton donor in the class of superacids (11). Hydrogen fluoride was prepared by the dynamic dilution of hydrogen fluoride from pressurized gas cylinders that were certified according to calibration standards.

\section{Administration of hydrogen fluoride}

Hydrogen fluoride gas was administered directly from gas cylinders into the ventilation duct of the inhalation chamber through specially made orifices. The concentra- tion of hydrogen fluoride was precalculated according to the gas cylinder concentration, gas flow, and ventilation rate. The concentration of hydrogen fluoride was kept at a constant level for each person during the exposure by monitoring and measuring continuously from a sensor inside the inhalation chamber. In addition, the exact concentration of hydrogen fluoride was measured from the inhalation zone of each participant. Details about the chamber, the gas delivery system, and the analysis of hydrogen fluoride have been described earlier $(9,12)$.

The subjects were divided into 3 groups according to the hydrogen fluoride concentrations and the current $(0.6$ $\left.\mathrm{mg} / \mathrm{m}^{3}\right)$ and the former $\left(2.5 \mathrm{mg} / \mathrm{m}^{3}\right)$ time-weighted average (TWA) exposure limit for total fluorides in Norway: $\leq 0.6 \mathrm{mg} / \mathrm{m}^{3}$ (low), $0.7-2.4 \mathrm{mg} / \mathrm{m}^{3}$ (intermediate) and $2.5-5.2 \mathrm{mg} / \mathrm{m}^{3}$ (high) (9).

\section{Inhalation procedure}

Each subject was exposed for 60 minutes. The first 45 minutes the subjects were at rest. Then they performed a 15-minute ergometric test at a fixed work load of $75 \mathrm{~W}$. As hydrogen fluoride will adsorb on clothes and hair, the subjects were dressed in overalls and helmets to standardize the test. During the exposure a slightly negative pressure was maintained in the chamber to avoid hydrogen fluoride pollution to the surroundings.

\section{Bronchoalveolar lavage}

Bronchoscopy with BAL was performed. The procedure was done according to recommendations of the European Society of Pneumonology (13) and the Workshop Summary and Guidelines of 1991 (14) and 1992 (15). All the subjects were investigated in the supine position and after entering the airways, the tip of the fibreoptic bronchoscope was gently introduced in a wedge position in a subsegment of the middle lobe. Sterile, isotone saline warmed to body temperature was instilled using a $4 \times 60$ $\mathrm{ml}$ aliquot regime (13). Each portion was immediately aspirated at a suction pressure of $10 \mathrm{kPa}$ into a container placed in ice water. The recovery from the first instilled aliquot was separated and defined as the bronchial portion, reflecting the more proximal airways (14). The fluid recovered from the subsequent aliquots was pooled and defined as the bronchoalveolar portion, reflecting the more distal air spaces (15). The BAL fluid was spun at $250 \mathrm{~g}$ at $4^{\circ} \mathrm{C}$ for 10 minutes. The supernatant was frozen at $-70^{\circ} \mathrm{C}$ until further analysis. The cell pellet was resuspended in $1 \mathrm{ml}$ of sterile phosphate-buffered saline (PBS) with $\mathrm{pH} 7.3$ (PBS-A).

\section{Analysis of isolated cells}

Smears were stained using May Grünwald Giemsa, and cell differential counts were performed after blinding. More than 200 cells were counted. By mistake, total cells were not counted in a Bürker chamber. Smears fixed in 
acetone for 10 minutes were used to assess the percentage of CD3-positive cells as a marker of T-lymphocytes. Anti-CD3 FITC-conjugated (FITC = fluorescein isothiocyanate) monoclonal antibodies were used for incubation (Becton Dickinson AB, Stockholm, Sweden) for 3 hours, $4^{\circ} \mathrm{C}$, in the dark. With the use of fluorescent light microscopy (Nicon Optiphot) CD3-positive cells were counted. The slides were coded, and the counts were performed independently by 2 investigators, determining the percentage of positive cells per 1000 cells. The mean values of these counts were used.

\section{Analyses of noncellular components}

All soluble components were analyzed in duplicate. Eosinophilic cation protein (ECP) was analyzed with a radioimmunoassay (RIA) kit (Pharmacia, Uppsala, Sweden). The detection limit was $2 \mu \mathrm{g} / \mathrm{l}$, and the intra- and interassay variations were $<9 \%$. Myeloperoxidase (MPO) was analyzed with a RIA kit (Pharmacia, Uppsala, Sweden). The detection limit was $4 \mu \mathrm{g} / \mathrm{l}$. The intra- and interassay variations were $<6 \%$ and $12 \%$, respectively.

IL-1 $\alpha$, IL-1 $\beta$, IL-3, IL-4 and IL-6 (IL = interleukin) were measured using commercially available immunoassay kits (R\&D systems, Minneapolis, USA). For IL$1 \alpha$, IL- $1 \beta$ and IL- 4 the detection limit was $0.3 \mathrm{pg} / \mathrm{ml}$, whereas the intra- and interassay precision values were $<2 \%$ and $6 \%$ for $I L-1 \alpha,<2 \%$ and $7 \%$ for IL- $1 \beta$, and $<7 \%$ and $10 \%$ for IL-4, respectively. For IL-3 the detection limit was $7.4 \mathrm{pg} / \mathrm{ml}$ and the intra- and interassay precision values were less than 5\%. For IL-6 the detection limit was $0.094 \mathrm{pg} / \mathrm{ml}$ and the intraassay precision range was $4-11 \%$, while the interassay precision range was 7 $29 \%$.

Methyl histamine was analyzed with an RIA kit (Pharmacia, Uppsala, Sweden). The detection limit was $0.05 \mu \mathrm{g} / \mathrm{l}$. The intra- and interassay variation values were $<6 \%$ and $11 \%$, respectively.

E-selectin and intercellular adhesion molecule-1 (ICAM-1) were analyzed with enzyme-linked immunosorbent assay (ELISA) kits (R\&D Systems, England). For E-selectin the detection limit was $0.1 \mathrm{ng} / \mathrm{ml}$, and for ICAM-1 it was $0.35 \mathrm{ng} / \mathrm{ml}$, whereas the intra- and interassay variations were $3 \%$ and $6 \%$ and $8 \%$, respectively.

Albumin was measured using a nephelometric method (Behring Diagnostica, Norway AS). The coefficient of variation was $7 \%$. The total amount of protein was determined using a turbidimetric endpoint method (Boehringer Mannheim). The coefficient of variation was $2.5 \%$.

For the fibronectin analyses a modification of the double-sandwich enzyme-linked immunosorbent assay (ELISA) (Kabi Pharmacia, Uppsala, Sweden), described by Rennard \& Crystal (16), was used. Microtiter plates (NUNC, Denmark) were coated with rabbit-antihuman fibronectin antibodies (Dakopatts, Denmark) diluted
1:2000 in carbonate buffer with $\mathrm{pH} 9.6$. After incubation at room temperature for 24 hours, the titer plates were carefully washed. PBS containing $0.05 \%$ albumin was added for 1 hour and then washed away. A BAL fluid sample was added in a diluted series together with horseradish peroxidase-labeled antihuman fibronectin 1:2000 (Dakopatts) as the second antibody, and the plates were incubated for 90 minutes. The amount of bound peroxidase, which is proportional to the amount of fibronectin in the sample, was measured by analyzing the enzymatic activity on ortho-phenylenediamine. Plasma fibronectin of nephelometric quality was provided by Sigma Chemicals and used as the standard. The detection limit was $10 \mu \mathrm{g} / \mathrm{l}$. The intra- and interassay variation was $<7 \%$.

Hyaluronan was analyzed using an RIA kit (Kabi Pharmacia Diagnostics, Uppsala, Sweden) adopted according to principles previously outlined (17). The detection limit for hyaluronan was $5 \mu \mathrm{g} / \mathrm{l}$. The intra- and interassay variability of the measurements was $<10 \%$.

\section{Statistics}

Wilcoxon's nonparametric signed rank test for paired observations was used for evaluating any change in the cells and the inflammatory mediators in BAL fluid from each person. All the calculations were performed using the statistical package for the social sciences (SPSS-PC) (18).

Our primary end points were changes in lymphocytes, CD3-positive cells, and neutrophils in the BAL fluid. This study is, to our knowledge, a pioneer work regarding specific cell response to hydrogen fluoride in a human experimental provocation setting. All data from the soluble components without and with Bonferoni's corrections (ie, P-value times the number of analyses) are therefore presented. To investigate the difference in the effect between the 3 exposure groups, a Kruscal Wallis test was performed.

Spearman's correlation coefficient was used to indicate the bivariate correlation of the individual differences in CD3-positive cells and lymphocytes in the bronchial and bronchoalveolar portions and between the differences in the 2 variables within each portion of $\mathrm{BAL}$ fluid. The same analysis was performed to estimate the correlations between the differences in the cells and the soluble mediators.

\section{Results}

\section{Isolated cells}

The percentage of CD3-positive cells in the bronchial and bronchoalveolar portions before and after hydrogen fluoride exposure is presented individually for the 3 concentration groups (low, intermediate, and high) in 
figures 1 and 2, respectively. A significant increase $(\mathrm{P}=0.03)$ in the percentage of $\mathrm{CD} 3$-positive cells in the bronchial portion occurred in the intermediate and high exposure groups, and for the bronchoalveolar portion there was a significant increase $(\mathrm{P}=0.04)$ in the high exposure group. Data from the cell differential counts from the bronchial and bronchoalveolar portions are presented in tables 1 and 2, respectively. There was a significant increase in the percentage of lymphocytes in the bronchial and bronchoalveolar portions in the intermediate exposure group. Since no dose-response effect was found in the scatterplots and no significant difference was found between the exposure groups by the Kruscal Wallis test, the P-values for each group are not shown in the tables.

There was a significant correlation between the individual changes in the percentage of CD3-positive cells and the changes in the percentage of lymphocytes from the bronchoalveolar portion (Spearman's correlation coefficient $r=0.68, P=0.008$ ), while there was no signifi-

\section{a}

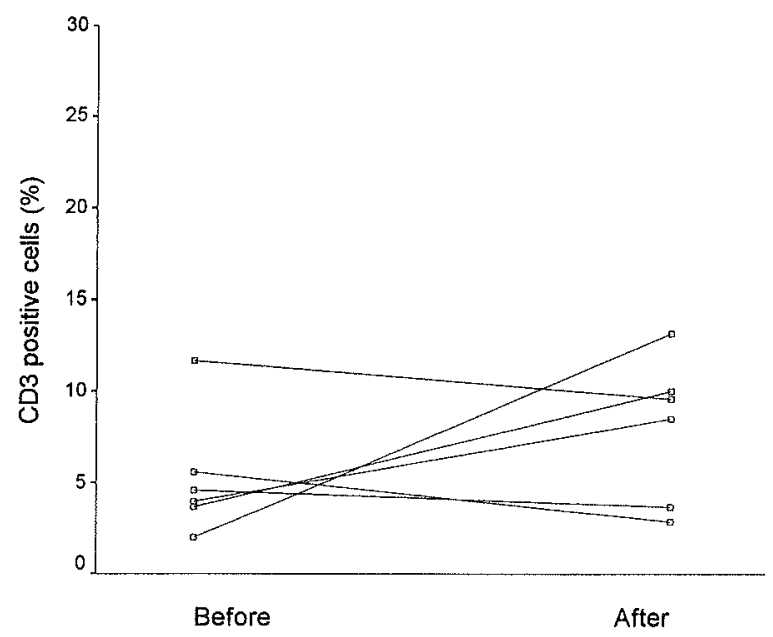

C

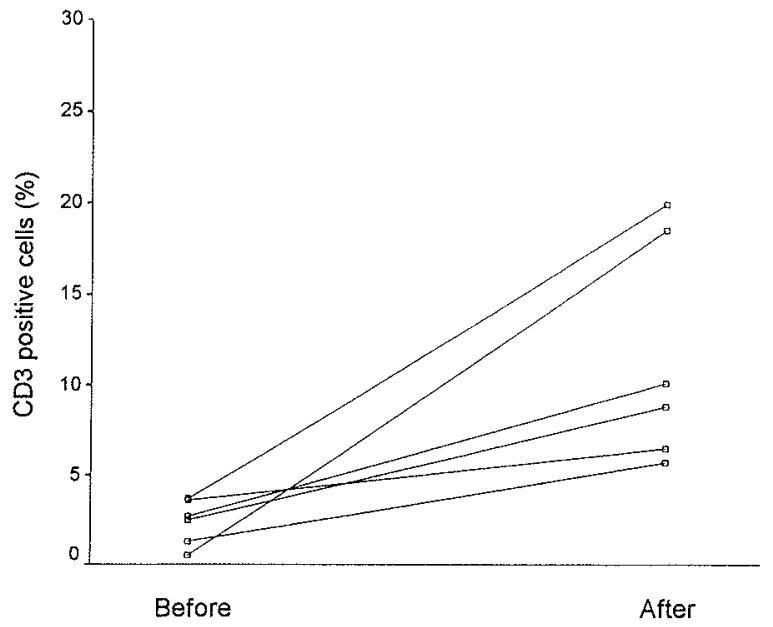

cant corresponding correlation for the bronchial portion $(r=0.25)$. A significant correlation was observed between the differences in the percentage of CD3-positive cells in the bronchial and bronchoalveolar portions (Spearman's correlation coefficient $\mathrm{r}=0.77, \mathrm{P}=0.000$ ) and between the changes in the percentage of lymphocytes in the 2 portions $(r=0.53, P=0.04)$.

\section{Noncellular components}

The median recovered volume of the bronchial portion from the reference $\mathrm{BAL}$ was $20 \mathrm{ml}$ (interquartile range $19-22 \mathrm{ml}$ ), which did not differ significantly from the median postexposure bronchial portion values of $19 \mathrm{ml}$ (interquartile range $16-22 \mathrm{ml}$ ). Correspondingly, the median recovery for the bronchoalveolar portion was 104 (interquartile range $90-121$ ) $\mathrm{ml}$ before and 117 (interquartile range 91-129) $\mathrm{ml}$ after exposure (not significant).

Data obtained on soluble components from the reference and the postexposure bronchoscopies are presented

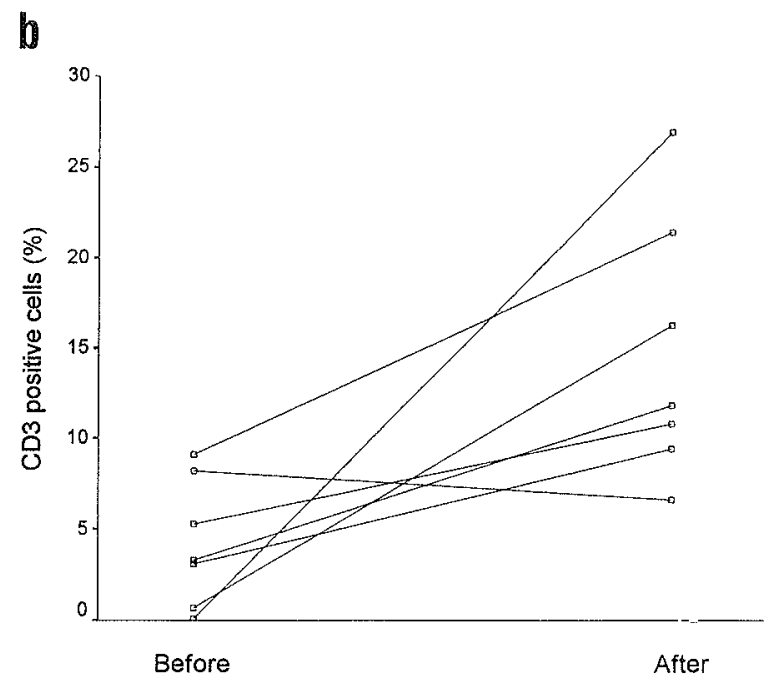

Figure 1. Percentage of CD3-positive cells in the bronchial portion of bronchoalveolar lavage fluid individually before and 24 hours after exposure to hydrogen fluoride in the low $\left(\leq 0.6 \mathrm{mg} / \mathrm{m}^{3}\right)$ (a), intermediate $\left(0.7-2.4 \mathrm{mg} / \mathrm{m}^{3}\right)(\mathrm{b})$, and high $\left(2.5-5.2 \mathrm{mg} / \mathrm{m}^{3}\right)$ (c) concentration groups.

Scand J Work Environ Health 1999, vol 25, no 4 
a

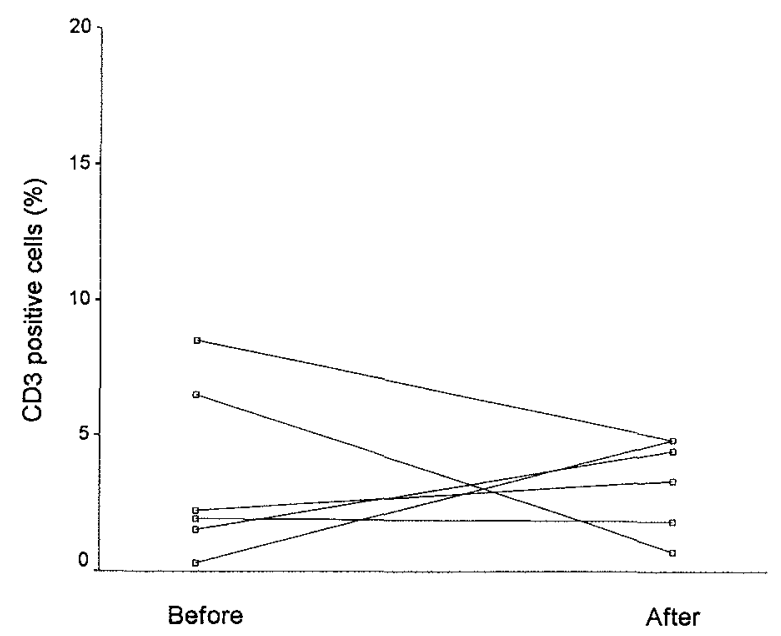

C

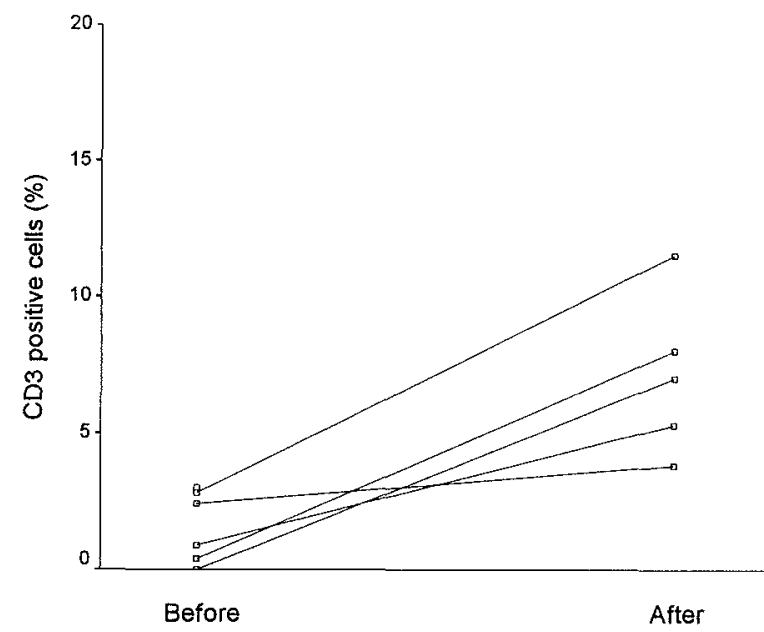

in tables 3 and 4 for the bronchial and bronchoalveolar portions, respectively. MPO and IL-6 increased significantly in the bronchial portion in the high-exposure group. A decrease was found for methyl histamine in the high-exposure group, while E-selectin was decreased when all the exposures were analyzed together. The median (with the interquartile range) concentrations for fibronectin before and after the exposure were $1600(950$ $2100)$ and $1250(650-2300) \mu \mathrm{g} / \mathrm{l}$, respectively. The corresponding values for hyaluronan were $27.1(23.8-30.5)$ and $25.5(21.2-35.0) \mu \mathrm{g} / \mathrm{l}$.

As can be seen in table 4, there was a significant decrease in ICAM-1, albumin, and total protein in the intermediate exposure group. The median (with the interquartile range) concentration for IL-3 before exposure was $50(36-86) \mathrm{pg} / \mathrm{ml}$, and after exposure it was 49 $(42-90) \mathrm{pg} / \mathrm{ml}$ for the entire group. ECP was close to the detection limit in both portions before and after the exposure (data not shown). IL-1 $\alpha$, IL-1 $\beta$, and IL-4 were b

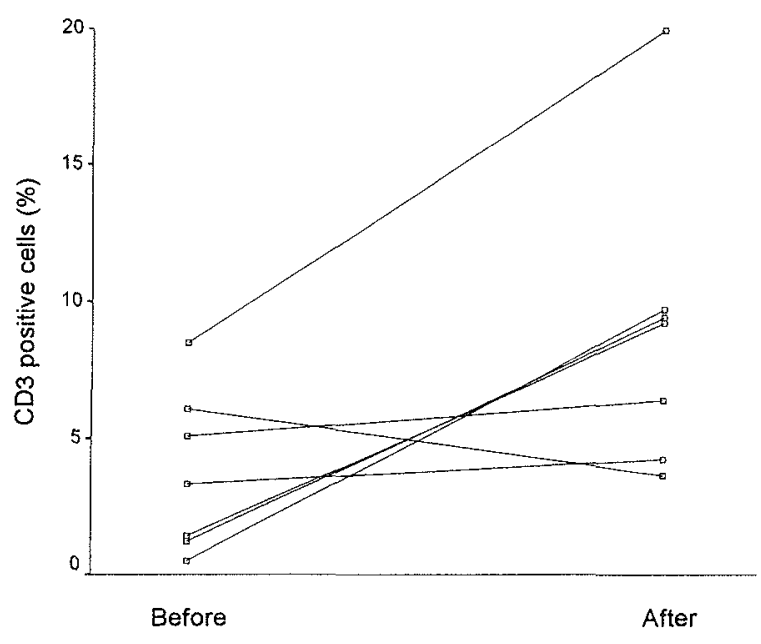

Figure 2. Percentage of CD3-positive cells in the bronchoalveolar portion of bronchoalveolar lavage fluid individually before and 24 hours after exposures to hydrogen fluoride in the low $\left(\leq 0.6 \mathrm{mg} / \mathrm{m}^{3}\right)$ (a), intermediate $\left(0.7-2.4 \mathrm{mg} / \mathrm{m}^{3}\right)(\mathrm{b})$, and high $\left(2.5-5.2 \mathrm{mg} / \mathrm{m}^{3}\right)(\mathrm{c})$ concentration groups.

not detectable in the control bronchoalveolar portion or in the exposed bronchoalveolar portion.

After Bonferoni's corrections for multiple testing, only the change in MPO in the bronchial portion in "all exposures" was significant among the soluble markers (table 3).

There was a significant correlation between the individual changes in MPO and the differences in neutrophils in the bronchial portion and the bronchoalveolar portion (Spearman's correlation coefficient $\mathrm{r}=0.51, \mathrm{P}=0.04$ and $\mathrm{r}=0.92, \mathrm{P}=0.000$, respectively).

\section{Discussion}

Our study shows that the exposure of healthy subjects to hydrogen fluoride concentrations above $0.6 \mathrm{mg} / \mathrm{m}^{3} \mathrm{can}$ induce an inflammatory response in the airways. The 
Table 1. Cell differentials (\%) in the bronchial portion (median and interquartile range) before and after exposure in the 3 hydrogen fluoride exposure groups ( $\mathrm{N}=$ number of subjects). Wilcoxon's rank sum test for paired observations.

\begin{tabular}{|c|c|c|c|c|c|c|c|c|}
\hline \multirow[t]{3}{*}{ Type of cell } & \multicolumn{6}{|c|}{ Hydrogen fluoride exposure groups } & \multicolumn{2}{|c|}{ All exposures $(N=15)$} \\
\hline & \multicolumn{2}{|c|}{$0.2-0.6 \mathrm{mg} / \mathrm{m}^{3}(\mathrm{~N}=5)$} & \multicolumn{2}{|c|}{$0.7-2.4 \mathrm{mg} / \mathrm{m}^{3}(\mathrm{~N}=6)$} & \multicolumn{2}{|c|}{$2.5-5.2 \mathrm{mg} / \mathrm{m}^{3}(\mathrm{~N}=4)$} & \multirow[t]{2}{*}{ Median } & \multirow{2}{*}{$\begin{array}{l}\text { Interquartile } \\
\text { range }\end{array}$} \\
\hline & Median & $\begin{array}{c}\text { Interquartile } \\
\text { range }\end{array}$ & Median & $\begin{array}{l}\text { Interquartile } \\
\text { range }\end{array}$ & Median & $\begin{array}{l}\text { Interquartile } \\
\text { range }\end{array}$ & & \\
\hline \multicolumn{9}{|l|}{ Eosinophils } \\
\hline Before & 0 & $0-0.6$ & 0 & $0-0.1$ & 0 & & 0 & $0-0$ \\
\hline After & 0 & $0-0.7$ & 0 & $0-0.4$ & 0 & $0-0.2$ & $\begin{array}{r}0 \\
P=0.74\end{array}$ & $0-0.3$ \\
\hline \multicolumn{9}{|l|}{ Neutrophils } \\
\hline Before & 0 & $0-1.4$ & 0.3 & $0-1.1$ & 0 & . & 0 & $0-0.5$ \\
\hline After & 0 & $0-0.5$ & 3.6 & $0.4-4.6$ & 0 & r & $\begin{array}{r}0 \\
P=0.39\end{array}$ & $0-3.0$ \\
\hline \multicolumn{9}{|l|}{ Lymphocytes } \\
\hline Before & 6.3 & $0-8.5$ & 3.5 & $2.0-5.0$ & 0.9 & $0.1-5.4$ & 3.1 & $0-6.7$ \\
\hline After & 6.4 & $0.9-14.5$ & 21.8 & $16.6-33.3$ & 9.2 & $6.2-12.2$ & $\begin{array}{r}12.3 \\
P=0.004\end{array}$ & $6.4-18.6$ \\
\hline \multicolumn{9}{|l|}{ Macrophages } \\
\hline Before & 93.7 & $89.6-100$ & 96.2 & $94.7-97.1$ & 99.2 & $94.7-99.9$ & 96.9 & $93.3-99.6$ \\
\hline After & 93.0 & $85.4-98.5$ & 75.9 & $62.8-79.7$ & 90.7 & $87.8-93.8$ & $\begin{array}{r}87.4 \\
P=0.003\end{array}$ & $77.2-93.0$ \\
\hline
\end{tabular}

Table 2. Cell differentials (\%) in the bronchoalveolar portion (median and interquartile range) before and after exposure in the 3 hydrogen fluoride exposure groups ( $N=$ number of subjects). Wilcoxon's rank sum test for paired observations.

\begin{tabular}{|c|c|c|c|c|c|c|c|c|}
\hline \multirow[t]{3}{*}{ Type of cell } & \multicolumn{6}{|c|}{ Hydrogen fluoride exposure groups } & \multicolumn{2}{|c|}{ All exposures $(\mathrm{N}=15)$} \\
\hline & \multicolumn{2}{|c|}{$0.2-0.6 \mathrm{mg} / \mathrm{m}^{3}(\mathrm{~N}=5)$} & \multicolumn{2}{|c|}{$0.7-2.4 \mathrm{mg} / \mathrm{m}^{3}(\mathrm{~N}=6)$} & \multicolumn{2}{|c|}{$2.5-5.2 \mathrm{mg} / \mathrm{m}^{3}(\mathrm{~N}=4)$} & \multirow[t]{2}{*}{ Median } & \multirow{2}{*}{$\begin{array}{l}\text { Interquartile } \\
\text { range }\end{array}$} \\
\hline & Median & $\begin{array}{l}\text { Interquartile } \\
\text { range }\end{array}$ & Median & $\begin{array}{l}\text { Interquartile } \\
\text { range }\end{array}$ & Median & $\begin{array}{l}\text { Interquartile } \\
\text { range }\end{array}$ & & \\
\hline \multicolumn{9}{|l|}{ Eosinophils } \\
\hline Before & 0 & & 0 & $0-0.1$ & 0 & $0-0.2$ & 0 & $0-0$ \\
\hline After & 0 & $0-0.2$ & 0 & $0-0.4$ & 0 & $0-0.2$ & $\begin{array}{r}0 \\
\mathrm{P}=0.46\end{array}$ & $0-0.2$ \\
\hline \multicolumn{9}{|l|}{ Neutrophils } \\
\hline Before & 0 & $0-3.7$ & 0.2 & $0-1.0$ & 0 & & 0 & $0-0.3$ \\
\hline After & 0 & & 2.2 & $0.6-6.9$ & 0 & $0-0.2$ & $P=0.67$ & $0-1.7$ \\
\hline \multicolumn{9}{|l|}{ Lymphocytes } \\
\hline Before & 1.0 & $0-3.4$ & 3.2 & $0-6.4$ & 0.3 & $0-4.7$ & 1.0 & $0-4.9$ \\
\hline After & 2.2 & $0-9.0$ & 12.9 & $10.6-20.9$ & 9.4 & $5.5-13.2$ & $P=0.002$ & $5.0-13.4$ \\
\hline \multicolumn{9}{|l|}{ Macrophages } \\
\hline $\begin{array}{l}\text { Before } \\
\text { After }\end{array}$ & $\begin{array}{l}98.0 \\
97.5\end{array}$ & $\begin{array}{l}93.5-100 \\
91.1-100\end{array}$ & $\begin{array}{l}95.5 \\
83.0\end{array}$ & $\begin{array}{l}93.1-99.8 \\
72.9-88.5\end{array}$ & $\begin{array}{l}99.8 \\
90.5\end{array}$ & $\begin{array}{l}95.1-100 \\
86.8-95.3\end{array}$ & $\begin{array}{r}98.0 \\
88.2 \\
P=0.002\end{array}$ & $\begin{array}{l}93.6-100 \\
86.0-94.7\end{array}$ \\
\hline
\end{tabular}

inflammatory response appeared primarily as a relative increase in lymphocytes, especially CD3-positive cells. Lymphocytosis has previously been reported after exposure to other occupational toxicants, such as nitrogen dioxide and sulfur dioxide with peak values 24 hours after exposure $(19,20)$. The mechanisms for the recruitment of lymphocytes (CD3-positive cells) in the persons exposed to hydrogen fluoride are unclear. Other studies have identified several factors involved in lymphocytosis due to toxicant exposure or lung disease. Experiments with adenovirus-vector-mediated gene transfer have demonstrated that IL- 6 promotes lymphocytosis in the rat (21). Such a role for IL-6 in the recruitment of lymphocytes is of interest for our study since hydrogen fluoride induced a significant increase in IL-6 in the highexposure group in the bronchial portion, even though it was not significant after Bonferoni's corrections.

Exposures to other toxicants, like ozone (22) and nitrogen dioxide (20) have been shown to elicit a neutrophilic response in BAL fluid 24 hours after exposure. Cytokines such as IL-8 in humans (23) and macrophage inflammatory protein 2 (MIP-2) in rats $(24,25)$ are potent chemo-attracting agents for neutrophilic cells. In our study, we could not observe any increase in the number of neutrophils in the persons exposed to hydrogen fluoride, although MPO was significantly increased in the bronchial portion. These findings may reflect an activation of neutrophils to release MPO, or the number of 
Table 3. Median value and interquartile range for soluble components in the bronchial portion of bronchoalveolar lavage fluid before and after exposure in the 3 hydrogen fluoride exposure groups ( $N=$ number of subjects).

\begin{tabular}{|c|c|c|c|c|c|c|c|c|}
\hline \multirow[t]{3}{*}{ Type of cell } & \multicolumn{6}{|c|}{ Hydrogen fluoride exposure groups } & \multicolumn{2}{|c|}{ All exposures $(N=19)$} \\
\hline & \multicolumn{2}{|c|}{$0.2-0.6 \mathrm{mg} / \mathrm{m}^{3}(\mathrm{~N}=6)$} & \multicolumn{2}{|c|}{$0.7-2.4 \mathrm{mg} / \mathrm{m}^{3}(\mathrm{~N}=7)$} & \multicolumn{2}{|c|}{$2.5-5.2 \mathrm{mg} / \mathrm{m}^{3}(\mathrm{~N}=6)$} & \multirow[t]{2}{*}{ Median } & \multirow{2}{*}{$\begin{array}{l}\text { Interquartile } \\
\text { range }\end{array}$} \\
\hline & Median & $\begin{array}{l}\text { Interquartile } \\
\text { range }\end{array}$ & Median & $\begin{array}{l}\text { Interquartile } \\
\text { range }\end{array}$ & Median & $\begin{array}{l}\text { Interquartile } \\
\text { range }\end{array}$ & & \\
\hline \multicolumn{9}{|c|}{ Myeloperoxidase (ng/ml) } \\
\hline Before & 12.0 & $7.4-21.8$ & 7.4 & $5.1-12.9$ & 11.1 & $7.9-22.6$ & 11.2 & $6.2-15.4$ \\
\hline After & 17.7 & $12.2-29.9$ & 21.9 & $13.9-28.0$ & 23.8 & $16.2-81.2$ & $\begin{array}{r}21.7 \\
P=0.005^{a}\end{array}$ & $15.0-28.0$ \\
\hline \multicolumn{9}{|c|}{ Interleukin-6 (pg/ml) } \\
\hline Before & $2.5^{b}$ & $1.8-3.4$ & 3.8 & $2.5-6.4$ & 2.7 & $2.1-4.2$ & $2.9^{\mathrm{c}}$ & $2.2-3.8$ \\
\hline After & 3.4 & $1.7-4.3$ & 4.2 & $3.5-4.8$ & 5.1 & $3.7-6.7$ & $\begin{array}{r}4.2 \\
P=0.09^{a}\end{array}$ & $3.3-5.1$ \\
\hline \multicolumn{9}{|c|}{ Methyl histamine $(\mu \mathrm{g} / \mathrm{l})$} \\
\hline Before & 0.15 & $0.11-0.27$ & 0.16 & $0.12-0.27$ & 0.23 & $0.21-0.34$ & 0.19 & $0.15-0.27$ \\
\hline After & 0.21 & $0.14-0.68$ & 0.19 & $0.07-0.36$ & 0.19 & $0.13-0.22$ & $\begin{array}{r}0.19 \\
P=0.72^{\mathrm{a}}\end{array}$ & $0.14-0.24$ \\
\hline \multicolumn{9}{|c|}{ ICAM-1 (ng/ml) } \\
\hline Before & 119.9 & $83.1-146.7$ & 103.9 & $88.3-126.2$ & 83.2 & $75.0-148.1$ & 103.9 & $80.8-143.3$ \\
\hline After & 93.4 & $59.7-113.1$ & 123.5 & $106.2-135.8$ & 97.5 & $78.8-100.5$ & $\begin{array}{r}104.7 \\
P=0.97^{\mathrm{a}}\end{array}$ & $82.2-123.5$ \\
\hline \multicolumn{9}{|c|}{ E-selectin (ng/ml) } \\
\hline Before & 0.29 & $0.07-0.75$ & 0.18 & $0.05-0.49$ & 0.18 & $0.05-0.49$ & 0.20 & $0.05-0.40$ \\
\hline After & 0.05 & $0.02-0.12$ & 0.0 & $0.0-0.08$ & 0.0 & $0.0-0.12$ & $\begin{array}{r}0.05 \\
P=0.007^{\mathrm{a}}\end{array}$ & $0.0-0.11$ \\
\hline
\end{tabular}

a Wilcoxon's rank sum test for paired observations.

b $N=5$

- $N=18$.

Table 4. Median value and interquartile range for soluble components in the bronchoalveolar portion of bronchoalveolar lavage fluid before and after exposure in the 3 hydrogen fluoride exposure groups ( $N=$ number of subjects).

\begin{tabular}{|c|c|c|c|c|c|c|c|c|}
\hline \multirow[t]{3}{*}{ Type of cell } & \multicolumn{6}{|c|}{ Hydrogen fluoride exposure groups } & \multicolumn{2}{|c|}{ All exposures $(N=19)$} \\
\hline & \multicolumn{2}{|c|}{$0.2-0.6 \mathrm{mg} / \mathrm{m}^{3}(\mathrm{~N}=6)$} & \multicolumn{2}{|c|}{$0.7-2.4 \mathrm{mg} / \mathrm{m}^{3}(\mathrm{~N}=7)$} & \multicolumn{2}{|c|}{$2.5-5.2 \mathrm{mg} / \mathrm{m}^{3}(\mathrm{~N}=6)$} & \multirow[t]{2}{*}{ Median } & \multirow{2}{*}{$\begin{array}{l}\text { Interquartile } \\
\text { range }\end{array}$} \\
\hline & Median & $\begin{array}{l}\text { Interquartile } \\
\text { range }\end{array}$ & Median & $\begin{array}{l}\text { Interquartile } \\
\text { range }\end{array}$ & Median & $\begin{array}{l}\text { Interquartile } \\
\text { range }\end{array}$ & & \\
\hline \multicolumn{9}{|c|}{ Myeloperoxidase (ng/mll) } \\
\hline Before & 2.0 & $2.0-12.3$ & 6.4 & $4.2-16.4$ & 2.0 & $2.0-10.4$ & 4.1 & $2.0-8.5$ \\
\hline After & 2.0 & $2.0-2.0$ & 5.8 & $2.0-18.6$ & 2.0 & $2.0-12.2$ & $\begin{array}{r}2.0 \\
P=0.64^{a}\end{array}$ & $2.0-5.8$ \\
\hline \multicolumn{9}{|c|}{ Interleukin-6 (pg/ml) } \\
\hline Before & 0.7 & $0.6-1.4$ & 2.1 & $1.6-4.1$ & 1.1 & $0.8-2.0$ & 1.2 & $0.8-2.1$ \\
\hline After & 1.0 & $0.4-1.3$ & 1.5 & $0.4-2.3$ & 1.1 & $0.7-2.0$ & $\begin{array}{r}1.1 \\
P=0.31^{a}\end{array}$ & $0.5-1.6$ \\
\hline \multicolumn{9}{|c|}{ ICAM-1 (ng/ml) } \\
\hline Before & 40.0 & $21.0-57.4$ & 59.5 & $51.4-70.4$ & 29.5 & $25.4-32.8$ & 41.3 & $27.5-59.5$ \\
\hline After & 43.9 & $26.4-63.0$ & 31.4 & $22.3-49.0$ & 24.3 & $22.2-33.2$ & $\begin{array}{r}31.4 \\
P=0.04^{a}\end{array}$ & $22.8-49.0$ \\
\hline \multicolumn{9}{|c|}{ E-selectin (ng/ml) } \\
\hline Before & 0.08 & $0.01-0.18$ & 0.17 & $0.0-0.48$ & 0.0 & $0.0-0.06$ & 0.05 & $0.0-0.18$ \\
\hline After & 0.04 & $0.02-0.19$ & 0.01 & $0.0-0.20$ & 0.0 & $0.0-0.02$ & $\begin{array}{r}0.02 \\
P=0.08^{\mathrm{a}}\end{array}$ & $0.0-0.06$ \\
\hline \multicolumn{9}{|c|}{ Albumin (mg/l) } \\
\hline Before & 40 & $28-70$ & 40 & $40-80$ & 35 & $28-55$ & 40 & $30-70$ \\
\hline After & 40 & $28-63$ & 30 & $20-40$ & 20 & $20-33$ & $\begin{array}{r}30 \\
P=0.05^{\mathrm{a}}\end{array}$ & $20-40$ \\
\hline \multicolumn{9}{|c|}{ Total protein $(\mathrm{mg} / \mathrm{l})$} \\
\hline Before & 50 & $30-90$ & 60 & $40-130$ & 40 & $30-95$ & 50 & $30-90$ \\
\hline After & 45 & $10-80$ & 30 & $20-50$ & 25 & $10-55$ & $\begin{array}{r}30 \\
P=0.04^{a}\end{array}$ & $10-50$ \\
\hline
\end{tabular}

a Wilcoxon's rank sum test for paired observations. 
neutrophilic cells peaked at a much earlier time point than 24 hours, leaving some neutrophils to release more MPO (26). Although it remains unclear which, it should be noted that MPO correlates with the number of neutrophilic cells in both the bronchial and bronchoalveolar portions.

Our data indicate that the inflammatory response seems to be prominent in the more proximal airways, as reflected in the percentage of CD3-positive cells in the bronchial and bronchoalveolar portions. Furthermore, MPO and IL-6 were elevated in the bronchial portion only. These findings could be due to the high water solubility of hydrogen fluoride, which leads to a higher absorption rate in the proximal airways with a concomitant cellular response. The observations correspond with those of studies of nose-breathing animals, in which it has been shown that more than $99 \%$ of hydrogen fluoride inhaled through the upper respiratory tract has been removed from the air stream before it reaches the lungs (27). Similarly, some studies have shown that most sulfur dioxide, which is also a highly water-soluble gas, is absorbed in the nasopharynx during nasal breathing and at only extremely high concentrations will alveolar deposition occur (28).

A striking observation in our study was the apparent decrease in total protein, albumin, ICAM-1, and E-selectin. These findings may be due to chance observations, as the results were not significant subsequent to Bonferoni's corrections, but they may also reflect true effects that deserve further study. Reductions in total protein and soluble mediators have been reported in other pollution studies, but so far little attention has been given to these observations (20). Recently, they have been of growing interest for the role of matrix metalloproteases (MMP), which are enzymes that contribute to airway remodeling. An increase in MMP has been observed in BAL fluid after exposure to diesel exhaust (29). It can be speculated that these enzymes may be involved in the reduction of total protein observed after hydrogen fluoride exposure.

The exposure of healthy, nonasthmatic subjects to hydrogen fluoride did not induce any changes in the number of eosinophils or ECP. This finding does not, however, exclude the possibility that hydrogen fluoride may elicit an eosinophil response in the BAL fluid from aluminum potroom workers with asthmatic symptoms. Furthermore, it should be strongly emphasized that the relationship between the ability of hydrogen fluoride to exert an acute inflammatory response in healthy subjects, reported in this study, and the long-term development of asthma in potroom workers (3), is unclear. Previous studies have, on one hand, indicated an association between the development of asthma and fluoride exposure (2), but, on the other, have demonstrated a role of inflammation in asthmatic development $(6,7)$. It remains to be clarified to what extent asthma in these workers is induced by a direct toxic effect with a subsequent inflammatory response or whether hydrogen fluoride acts as an occupational sensitizer.

It is of interest that the acute inflammatory response due to hydrogen fluoride exposure was found at concentrations that can occur in the atmosphere of the primary aluminum industry. Although, we cannot identify a clear dose-effect relationship and only found minor changes in BAL fluid $\leq 0.6 \mathrm{mg} / \mathrm{m}^{3}$ (ie, the present TWA exposure limit in Norway), this level should not be considered harmless in workers with continuous exposure to hydrogen fluoride, and regular monitoring of their respiratory health should therefore be mandatory.

In conclusion, hydrogen fluoride exposure at concentrations that can occur in the ambient air in the primary aluminum industry induces an inflammatory response in the airways of healthy subjects.

\section{Acknowledgments}

The authors want to thank Mari-Anne Boe for her excellent technical assistance; Fürst laboratories for undertaking the ECP analyses; Jan Tore Samuelsen, Hans Jørgen Dahlman, Nathalia Hemsen, Edel Lilleås, Jamshid Pourazar, and Ann Britt Lundstr $\varnothing \mathrm{m}$ for their laboratory assistance; and Dr Sven Ove Samuelsen and Professor Eva Skovlund for their statistical assistance.

The study was supported by the Working Environment Fund of the Confederation of Norwegian Business and Industry, the Nordic Aluminium Industry's Secretariate for Health, Environment and Safety, the Research Council of Norway, the Research Funds of the Norwegian Asthma and Allergy Association and Astra, Norway.

\section{References}

1. Abramson MJ, Wlodarczyk JH, Saunders NA, Hensley MJ. Does aluminium smelting cause lung disease? Am Rev Respir Dis 1989;139:1042-57.

2. Kongerud J, Boe J, Söyseth V, Naalsund A, Magnus P. Aluminium potroom asthma: the Norwegian experience. Eur Respir J 1994;7:165-72.

3. Kongerud J, Samuelsen SO. A longitudinal study of respiratory symptoms in aluminum potroom workers. Am Rev Respir Dis 1991;144:10-6.

4. Søyseth V, Kongerud J, Harr D, Strand O, Bolle R, Boe J. Relation of exposure to airway irritants in infancy to prevalence of bronchial hyper-responsiveness in schoolchildren. Lancet 1995;345:217-20.

5. Eklund A, Arns R, Blaschke E, Hed J, Hjertquist SO, Larsson $\mathrm{K}$, et al. Characteristics of alveolar cells and soluble components in bronchoalveolar lavage fluid from non-smoking aluminium potroom workers Br J Ind Med 1989;46:782-6.

6. Sears MR. The definition of asthma. Allergy 1993;48:12-6.

7. Mapp CE, Saetta M, Maestrelli P, Di Stefano A, Chitano P, Boschetto P, et al. Mechanisms and pathology of occupational 
asthma. Eur Respir J 1994; 7:544-54.

8. Söyseth V, Kongerud J, Ekstrand J, Boe J. Relation between exposure to fluoride and bronchial responsiveness in aluminium potroom workers with work related asthma-like symptoms. Thorax 1994;49:984-9.

9. Lund K, Ekstrand J, Boe J, Söstrand P, Kongerud J. Exposure to hydrogen fluoride: an experimental study in humans of concentrations of fluoride in plasma, symptoms and lung function. Occup Environ Med 1997;54:32-7.

10. Quanjer PH. Standardized lung function testing. Eur Respir J Suppl 1993;16:5-40.

11. Smith F, Ekstrand J. Fluoride in dentistry. In: Feierskov O, Ekstrand $\mathbf{J}$, Burt B, editors. The occurrence and chemistry of fluoride. 2nd ed. Copenhagen: Munksgaard, 1996: chapter 1.

12. Söstrand P, Kongerud J, Wijnand E, Nilsen T, Skogland M, Boe J. A test chamber for experimental hydrogen fluoride exposure in humans. Am Ind Hyg Assoc J 1997;58:383-7.

13. Technical recommendations and guidelines for bronchoalveolar lavage (BAL): report of the European Society of Pneumology Task Group on BAL. Eur Respir J 1989;2:561-85.

14. Workshop summary and guidelines - investigative use of bronchoscopy, lavage and bronchial biopsies in asthma and other airway diseases. J Allergy Clin Immunol 1991;88(5):808-14.

15. Fabbri LM, De Rose V, Godard P, Boschetto P, Rossi GA. Guidelines and recommendations for the clinical use of bronchoalveolar lavage in asthma. Eur Respir J 1992;2:8:11420.

16. Rennard SI, Crystal RG. Fibronectin in human bronchoalveolar lavage fluid. J Clin Invest 1981B;69:113-22.

17. Nettelbladt $\mathrm{O}$, Bergh $\mathbf{J}$, Schenholm M, Tengblad A, Hällgren R. Accumulation of hyaluronic acid in the alveolar interstitial tissue in bleomycin induced alveolitis. Am Rev Respir Dis 1989;139:759-62.

18. Norusis MJ. - SPSS/PC+: statistical package for the social sciences. Chicago (IL): SPSS Inc, 1989.

19. Helleday R, Sandström T, Stjernberg N. Differences in bronchoalveolar cell response to nitrogen dioxide exposure be- tween smokers and nonsmokers. Eur Respir J 1994;7:121320

20. Sandström T. Respiratory effects of air pollutants: experimental studies in humans. Eur Respir J 1995;8:976 -95

21. Xing Z, Braciak T, Jordana M, Croitoru K, Graham FL, Gauldie J. Adenovirus-mediated cytokine gene transfer at tissue sites: overexpression of $\mathrm{L}-6$ induces lymphocytic hyperplasia in the lung. J Immunol 1994;153:4059-69.

22. Koren HS, Devlin RB, Graham DE, Mann R, Mc Gee MP, Horstman DH, et al. Ozone-induced inflammation in the lower airways of human subjects. Am Rev Respir Dis 1989;139:407-15.

23. Matsushima K, Oppenheim JJ. Interleukin 8 and MCAF: novel inflammatory cytokines inducible by $\mathrm{IL} 1$ and TNF. Cytokine 1989;1:2-13.

24. Driscoll KE, Hassenbein DG, Howard BW, Isfort RJ, Cody $\mathrm{D}$, Tindal MH, et al. Cloning, expression and functional characterization of rat MIP-2: a neutrophil chemoattractant and epithelial cell mitogen. J Leukoc Biol 1995;58:359—64.

25. Gauldie J, Graham F, Xing Z, Braciak T, Foley R, Sime PJ Adenovirus-vector-mediated cytokine gene transfer to lung tissue. Anal NY Acad Sci 1996:235-44.

26. Klebanoff SJ, Clark RA, editors. Myeloperoxidase. In: The neutrophil: function and clinical disorders. Amsterdam: Elsevier/North Holland Medical Press, 1978:44-8.

27. Morris JB, Smith F. Regional deposition and absorption of inhaled hydrogen fluoride in the rat. Toxicol Appl Pharmacol 1982;62:81-9.

28. Frank NR, Yoder RE, Brain JD, Yokoyama E. SO2 (35 Slabelled) absorption by nose and mouth under conditions of varying concentrations and flow. Arch Environ Health $1969 ; 18: 315-22$.

29. Warner JA, Brearley-Smith J, Holgate ST, Blomberg A, Sandström T, Shute JK. Increased levels of matrix metalloproteases in bronchoalveolar lavage (BAL) following exposure to diesel exhaust. Am J Respir Crit Care Med 1997;155:A425.

Received for publication: 25 June 1998 